\title{
Uji Bioaktivitas Antibakteri Senyawa murni dari Jamur Endofit Sporothrix sp Terhadap Bakteri Escherichia coli dan Staphylococcus aureus
}

\author{
Dewi Yudiana Shinta ${ }^{1}$, Yusmarini ${ }^{2}$, Herix Sonata MS $^{3}$, Hilwan Yuda Teruna ${ }^{4}$ and Saryono ${ }^{4}$ \\ ${ }^{1}$ STIKES Perintis Padang, Indonesia \\ ${ }^{2}$ Fakultas Pertanian Universitas Riau Kampus Bina widya Panam KM 12.5 Pekanbaru \\ ${ }^{3}$ ITP Padang Indonesia \\ ${ }^{4}$ Fakultas FMIPA Universitas Riau Kampus Bina widya Panam KM 12.5 Pekanbaru
}

\begin{abstract}
Modern medicines that are developing now come from active ingredients isolated from plants that require large amounts of plants. The development of new drugs from endophytic fungi found obstacles in the amount of pure compounds produced. Therefore further research is needed by using endophytic fungi as a new antimicrobial producer. This study aims to see the ability or activity of pure compounds produced by Sporothrix sp endophytic fungi from Dahlia tuber (Dahlia variabilis). Test the activity of pure compounds produced by Sporothrix sp. Endophytic fungi on E. coli and Staphylococcus aureus

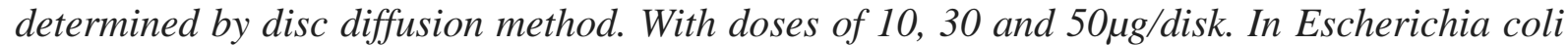
bacteria doses 10 and $50 \mu \mathrm{g} /$ disk gave significant inhibition of pure compounds from isolation compared to the positive control of ciprofloxacin, which was marked by a statistically significant test result $(p<0.05)$. In contrast to Staphylococcus aureus there was no significant difference in doses of both doses of 10.30 and $50 \mu \mathrm{g} / \mathrm{disk}$. Determination of pure compounds was carried out by HPLC and Infra Red Spectrophotometry.
\end{abstract}

Key Words: Dahlia bulbs (Dahlia variabilis), Endophytic fungi Sporothrix sp, E. coli, Staphylococcus aureus.

Pemakaian obat antibakteri sintesis secara terusmenerus tidak hanya membunuh bakteri itu sendiri namun juga mempercepat terjadinya resistensi patogen. Untuk itu diperlukan alternatif obat antibakteri yang aman yang berasal dari bahan alam.

Sumber bahan baru bioaktif yang banyak dieksplorasi sekarang ini adalah jamur endofit. Hal ini dikarenakan jamur endofit dapat menghasilkan metabolit sekunder yang dapat dikembangkan menjadi bahan baku obat. Senyawa yang dihasilkan jamur endofit seringkali memiliki aktifitas yang lebih besar dibandingkan aktivitas dari senyawa tumbuhan inangnya(1). Pembiakan atau kultur jamur endofit dapat dilakukan dalam jumlah yang sangat besar tanpa memerlukan lahan yang luas seperti tumbuhan. Pemanfaatan jamur endofit sebagai penghasil sumber bahan baku obat alami akan mereduksi kerusakan alam yang disebabkan oleh eksploitasi tumbuhan obat dalam jumlah yang besar.

Produksi senyawa antimikroba dari tanaman dalam jumlah massal membutuhkan tanaman dalam jumlah yang banyak, sehingga diperlukan lahan yang luas serta waktu yang relatif lebih lama menunggu masa pertumbuhan tanaman. Kendala tersebut dapat diatasi dengan mengisolasi senyawa metabolit sekunder dari mikroba. Salah satunya adalah mikroba endofit yang hidup dalam jaringan tanaman(2).

Fitriyah.dkk,(2014) melaporkan Jamur endofit umbi tanaman dahlia yang telah diisolasi adalah Monilia sp (LBKURCC 40), Fusarium sp (LBKURCC 41), Moniliella sp (LBKURCC 42), dan Sporothrix sp (LBKURCC43). Dari keempat isolat diatas mempunyai bioaktivitas antimikroba terhadap bakteri Gram positif, Gram negatif serta jamur. Fusarium sp (LBKURCC 41) dan Sporothrix sp (LBKURCC 43) adalah jamur endofit umbi dahlia yang menghasilkan metabolit sekunder yang mempunyai aktivitas antimikroba terhadap E.coli dan Staphylococcus aureus, tapi senyawa metabolit sekunder yang dihasilkan belum dimurnikan dan belum ditentukan struktur kimianya serta bioaktifitasnya terhadap mikroba penyebab penyakit infeksi juga belum dilakukan(3).

Penelitian ini bertujuan untuk melihat kemampuan atau aktivitas dari senyawa murni yang dihasilkan oleh jamur endofit Sporothrix 
sp dari umbi Dahlia.(Dahlia variabilis). Dalam penelitian ini akan ditemukan dosis berapa dari senyawa murni yang ditemukan dari metabolit sekunder jamur Sporothrix sp yang dapat menghambat pertumbuhan bakteri E.coli dan Staphylococcus aureus.

\section{BAHAN DAN METODE}

\section{Alat dan Bahan}

Alat-alat yang digunakan dalam penelitian ini adalah Autoclaf 1925x (Wiconsin Alumnium Foundry Co.Inc.Monitowoc), High Speed Micro Centrifuge Model CT 15RE, vortex mixer H-VM-300, Water Bath Grant SUB28, incubator Memmert, rotary shaker (Daihan Labtech Co.LTD), spektrofotometer IR Shimadzu Prestige 2100, HPLC, oven, cawan petri, jarum ose, bunsen, kompor gas, pengaduk kaca, pinset, kertas saring, inkubator, aluminium foil, mikroskop, cover glass, gelas obyek, gelas ukur, tabung reaksi, pipet volume, erlenmeyer, jangka sorong, botol media, shaker incubator, sentrifugasi, timbangan analitik dan silet.

Bahan -bahan yang digunakan adalah media Potato Dextrose Agar (PDA) no Cat 1.10130.0500, Sabouraud Dextrose Broth (SDB) No cat 1.08339.0500, Sabouraud Dextrose Agar (SDA), media Nutrient Agar (NA) No cat $1.05450,0500$, media Nutrient Broth (NB) no cat 1.05443.0500. (semua media diproduksi oleh Merck KGaA Germany), natrium klorida $(\mathrm{NaCl})$, media Huang et al (2007), Kalium Dihidrogen Pospat $\left(\mathrm{KH}_{2} \mathrm{PO}_{4}\right)$, Magnesium sulfat hepta hidrat $\left(\mathrm{MgSO}_{4} \cdot 7 \mathrm{H}_{2} \mathrm{O}\right)$, dan besi sulfat hepta hidrat $\left(\mathrm{FeSO}_{4} \cdot 7 \mathrm{H}_{2} \mathrm{O}\right)$. Milipore syringe filter $0,2 \mu \mathrm{m}$ (Puradisc TM $13 \mathrm{~mm}$ cat no 6786-1302), kertas cakram 6mm (macherey-nagel MN827ATD).Isolat jamur endofit Sporothrix sp LBKURCC 43 yang telah diisolasi dari umbi tanaman dahlia (Dahlia variabilis) pada penelitian sebelumnya (Lorenita,2011). Mikroorganisme yang digunakan dalam uji antimikroba adalah bakteri Stapylococcus aureus, Escherichia coli yang di dapat dari koleksi Fakultas Kedokteran Universitas Andalas Padang.

\section{Prosedur Penelitian.}

Produksi Isolat

Fermentasi dilakukan pada kondisi optimum yaitu suhu $37^{\circ} \mathrm{C}, \mathrm{pH} 4$, aerasi 50vvm, agitasi $150 \mathrm{ppm}$ dengan variasi media Huang et al dengan ammonium dan $\mathrm{Na} \mathrm{CMC}+$ sukrosa dengan volume 6 liter. Komposisi medianya dapat dilihat pada tabel 1 dibawah ini.

Tabel 1. Komposisi variasi media Huang et al (2007)

\begin{tabular}{cc}
\hline Komposisi & Berat atau volume \\
\hline $\mathrm{NaCMC}+$ Sukrosa & $42+126 \mathrm{~g}$ \\
$\mathrm{NaNO}_{3}$ & $18 \mathrm{~g}$ \\
$\mathrm{KH}_{2} \mathrm{PO}_{4}$ & $9 \mathrm{~g}$ \\
$\mathrm{Amonium} \mathrm{sulfat}$ & $9 \mathrm{~g}$ \\
$\mathrm{KCl}$ & $3 \mathrm{~g}$ \\
$\mathrm{MgSO}_{4} \cdot 7 \mathrm{H}_{2} \mathrm{O}$ & $3 \mathrm{~g}$ \\
$\mathrm{FeSO}_{4} \cdot 7 \mathrm{H}_{2} \mathrm{O}$ & $0,06 \mathrm{~g}$ \\
Aquadest & $6 \mathrm{~L}$ \\
\hline
\end{tabular}

\section{Ekstraksi Isolat}

Isolat diekstraksi dengan metoda kromatografi flash. Pemisahan lanjut dari suatu fraksi sehingga mendapatkan isolat murni dapat dilakukan dengan kromatografi flash. Besar kolom kromatografi flash yang digunakan berdiameter $2,5 \mathrm{~cm}$. Fasa diam yang digunakan silica gel 230-400 nm dengan perbandingan banyak silica gel kolom dengan sampel adalah 1:50-60. Silika gel dalam kolom dibuat dengan cara kering dengan cara silica dimasukkan ke dalam kolom yang telah berisi sedikit pelarut yang akan digunakan untuk elusi kemudian dikocok sehingga pelarut dan silica bercampur. Selanjutnya kolom ditekan dengan air pump agar silica memadat. Kemudian sejumlah sampel yang telah dilarutkan dalam sedikit pelarut yang akan digunakan ditempatkan diatas silica kolom. Sampel sebanyak 2,7 gram yang telah diimpregnasi dengan 3 gram silica dilakukan pemisahan lebih lanjut dengan menggunakan kromatografi flash.

\section{Pemisahan Ekstrak etil asetat Sporothrix sp dengan VLC (Kromatografi Vakum Cair)}

Kromatografi vakum cair (yang berdiameter $10 \mathrm{~cm}$ dan tinggi $20 \mathrm{~cm}$ ) diisi dengan silika gel $60 \mathrm{GF}_{254}$ hingga mencapai ketinggian lebih kurang $10 \mathrm{~cm}$. Pengisian kolom dilakukan dalam keadaan vakum, agar diperoleh kerapatan kemasan maksimum. Sebanyak 2,7 g sampel preadsorpsi dan kemudian dimasukkan kedalam kolom. Selanjutnya difraksinasi secara bergradien menggunakan pelarut n-heksanaetilasetat perbandingan 70:30 kenaikan kepolaran $10 \%$ sampai perbandingan metanoletil asetat (50:50) kenaikan kepolaran $10 \%$. Hasil pemisahan ditampung dalam erlemeyer yang telah diberi nomor dan dipekatkan dengan 
rotary evapaporator, selanjutnya dilakukan uji KLT untuk mengetahui jumlah komponen dari masing - masing fraksi. Fraksi yang memiliki pola noda yang sama digabungkan. Fraksi F3 F5 diperoleh berupa kristal kemudian dicuci dengan etil asetat dan selanjutnya dikritalisasi dengan diklorometan, dapat dilihat pada tabel 2 dibawah ini.

\section{Pemisahan Ekstrak etil asetat Sporothrix sp dengan VLC (Kromatografi Vakum Cair)}

Tabel 2. Fraksi-fraksi yang memiliki pola noda pada KLT

\begin{tabular}{ccc}
\hline $\begin{array}{c}\text { No } \\
\text { Fraksi }\end{array}$ & Eluen & Berat $(\mathrm{g})$ \\
\hline F1 & $\mathrm{H}: \mathrm{E}=7: 3$ & 0,3174 \\
F2 & $\mathrm{H}: \mathrm{E}=6: 4$ & 0,1311 \\
F3 & $\mathrm{H}: \mathrm{E}=5: 5$ & 0,3024 \\
F4 & $\mathrm{E}=100 \%$ & 0,6880 \\
F5 & $\mathrm{E}: \mathrm{M}=9: 1$ & $0,0,71$ \\
F6 & $\mathrm{E}: \mathrm{M}=8: 2$ & 0,1319 \\
F7 & $\mathrm{E}: \mathrm{M}=7: 3$ & 0,511 \\
F8 & $\mathrm{E}: \mathrm{M}=6: 4$ & 0,0637 \\
F9 & E:M $=5: 5$ & 0,049 \\
\hline
\end{tabular}

Pemisahan Ekstrak etil asetat Sporothrix sp dengan Kromatografi Flash

Kolom dapat dibuat dengan membuat bubur silika gel $(230$ - 400) dengan cara melarutkannya dengan pelarut $n$-heksana dan diaduk rata. Kemudian dituangkan ke dalam kolom secara perlahan-lahan. Silika gel dalam kolom dibuat padat dan permukaannya jangan sampai kering. Pengelusian kolom dilakukan dengan berbagai eluen yang memiliki kepolaran meningkat, mulai dari $n$-heksana $100 \%$, perbandingan $n$-heksana dengan etil asetat sampai etil asetat $100 \%$. Sebanyak 1,5 gram sampel dipreadsorbsi terlebih dahulu sebelum dimasukan ke dalam kolom, kemudian dielusi dengan pelarut hingga terbentuk pita-pita. Hasil fraksinasi yang keluar ditampung dalam vial yang telah diberi nomor.

Fraksi-fraksi hasil pemisahan dengan kromatografi kolom yang menunjukkan adanya kristal dilakukan uji KLT untuk mengetahui harga Rf (Retardation factor) yang sama sehingga dapat digabung. Kristal yang terbentuk direkristalisasi kemudian kristal hasil rekristalisasi dilakukan uji KLT dan uji HPLC.

Analisis HPLC ini dilakukan menggunakan metode gradien elusi. Sampel dilarutkan dengan metanol (HPLC grade) (1 mg dalam $1 \mathrm{~mL}$ metanol). Larutan kemudian disaring dengan penyaring whatman $0,45 \mu \mathrm{L}$.
Filtrat sebanyak $20 \mu \mathrm{L}$ diinjekkan ke dalam kolom, kemudian sampel dianalisis selama 20 menit menggunakan metode yang sesuai. Kolom yang digunakan pada HPLC adalah Shim-pack VP-ODS dengan panjang dan diameternya yaitu 150 x 4,6 mm. Kristal senyawa murni dikarakterisasi menggunakan spektroskopi IR.

\section{Uji aktivitas antimikroba senyawa murni (metoda Kirby Bauer)}

\section{Pembuatan media agar}

Media yang digunakan untuk uji antibakteri yaitu NA (Nutrient agar) dan media uji anti jamur yaitu PDA (potato dextrose agar). NA sebanyak 20 gram dilarutkan dalam 1000 $\mathrm{ml}$ aquadest dan dimasukkan ke dalam tabung reaksi, masing-masing sebanyak $15 \mathrm{ml}$. Media ditutup dan distrerilisasi pada suhu $121^{\circ} \mathrm{C}$ dan tekanan 15 psi selama 15 menit (4). PDA sebanyak 39 gram dilarutkan dalam $1000 \mathrm{ml}$ aquadest kemudian media dimasukkan ke dalam tabung reaksi, masing-masing sebanyak $15 \mathrm{ml}$. Media ditutup dan disterilisasi pada suhu $121^{\circ} \mathrm{C}$ dan tekanan 15 psi selama 15 menit (4).

\section{Peremajaan Mikroba}

Peremajaan Mikroba bertujuan untuk meremajakan kembali bakteri (Staphylococcus aureus dan Escherichia coli) dari agar miring ke dalam larutan NB. Media NB yang telah dibuat dimasukkan ke dalam tabung reaksi dan di sterilisasi. Bakteri dari agar miring diambil dengan menggunakan jarum ose steril, kemudian diinokulasikan ke dalam media NB. Tabung ditutup dengan kapas kemudian diinkubasi dalam inkubator pada suhu $37^{\circ} \mathrm{C}$ selama 24 jam.

\section{Uji Antibakteri}

Media dipanaskan sampai mencair dan didinginkan pada suhu $50^{\circ} \mathrm{C}$ dalam waterbath, kemudian ditambahkan $1 \mathrm{ml}$ biakan bakteri E.coli dan S.Aureus $\left(\mathrm{OD}_{600 \mathrm{~nm}}-0,1\right)(5)$ ke dalam tabung, kemudian dihomogenkan dan dituang ke dalam cawan petri. Setelah media memadat, kertas cakram yang telah dtetesi dengan sampel uji (konsentrasi $500 \mu \mathrm{g} / \mathrm{ml}, 300 \mu \mathrm{g} / \mathrm{ml}$ dan 100 $\mu \mathrm{g} / \mathrm{ml}$ ) diletakkan diatas media agar. Kontrol positif yang digunakan yaitu ciproflocaxin dengan konsentrasi $300 \mu \mathrm{g} / \mathrm{ml}$ dan kontrol negatif yaitu DMSO yang digunakan untuk melarutkan sampel. Cawan petri diinkubasi 
dalam inkubator pada suhu $37^{\circ} \mathrm{C}$. Diameter daerah hambat pertumbuhan bakteri diukur setelah diinkubasi 24 jam. Semua perlakuan secara aseptik dan diulang sebanyak dua kali.(4).

\section{HASIL}

Ekstrak kental yang dihasilkan dari proses evaporasi adalah 2,7 gram dari 6 liter fermentasi, dengan warna coklat tua dan bau khas amonia. Ekstrak kering yang diperoleh setelah proses penguapan adalah 0,3024 gram.

Hasil pemurnian 6 liter sampel hasil isolasi ekstrak jamur endofit Sporothrix $s p$ (LBKURCC 43) dilakukan dengan metode kromatografi lapis tipis (KLT) dengan berbagai variasi komposisi eluen memperlihatkan noda tunggal dan dilakukan berulang pada setiap komposisi.

Sebanyak 0,3024g sampel preadsorpsi dan kemudian dimasukkan kedalam kolom. Selanjutnya difraksinasi secara bergradien menggunakan pelarutnya heksana - etil asetat perbandingan 70:30 kenaikan kepolaran 10\% sampai perbandingan metanol-etil asetat (50:50) kenaikan kepolaran $10 \%$. Hasil pemisahan ditampung dalam erlemeyer yang telah diberi nomor dan dipekatkan dengan rotary evapaporator, selanjutnya dilakukan uji KLT untuk mengetahui jumlah komponen dari masing - masing fraksi. Fraksi yang memiliki pola noda yang sama digabungkan. Fraksi F3 F5 diperoleh berupa kristal yang murni kemudian dicuci dengan etil asetat dan selanjutnya dikritalisasi dengan diklorometan. Senyawa F3 dilakukan uji kemurnian dengan KLT dan HPLC yang dapat dilihat pada tabel 3 dibawah ini.

Tabel 3. Hasil uji KLT dari masing-masing fraksi.

\begin{tabular}{cccc}
\hline $\begin{array}{c}\text { No } \\
\text { Fraksi }\end{array}$ & Eluen & Berat (g) & $\begin{array}{c}\text { Jumlah } \\
\text { spot }\end{array}$ \\
\hline F1 & H:E $=7: 3$ & 0,3174 & 6 \\
F2 & H:E $=6: 4$ & 0,1311 & 5 \\
F3 & H:E $=5: 5$ & 0,3024 & 4 \\
F4 & E $=100 \%$ & 0,6880 & 4 \\
F5 & E:M $=9: 1$ & $0,0,71$ & 5 \\
F6 & E:M $=8: 2$ & 0,1319 & 4 \\
F7 & E:M $=7: 3$ & 0,511 & 5 \\
F8 & E:M $=6: 4$ & 0,0637 & 5 \\
F9 & E:M $=5: 5$ & 0,049 & 6
\end{tabular}

Pengukuran dengan menggunakan spektrum IR (infra red) menunjukkan adanya serapan yang khas dan tajam pada beberapa panjang gelombang. Hasil analisis spektrum infra merah senyawa F3 hasil isolasi ekstrak jamur endofit Sporothrix $s p$ terlihat pada Gambar 1.

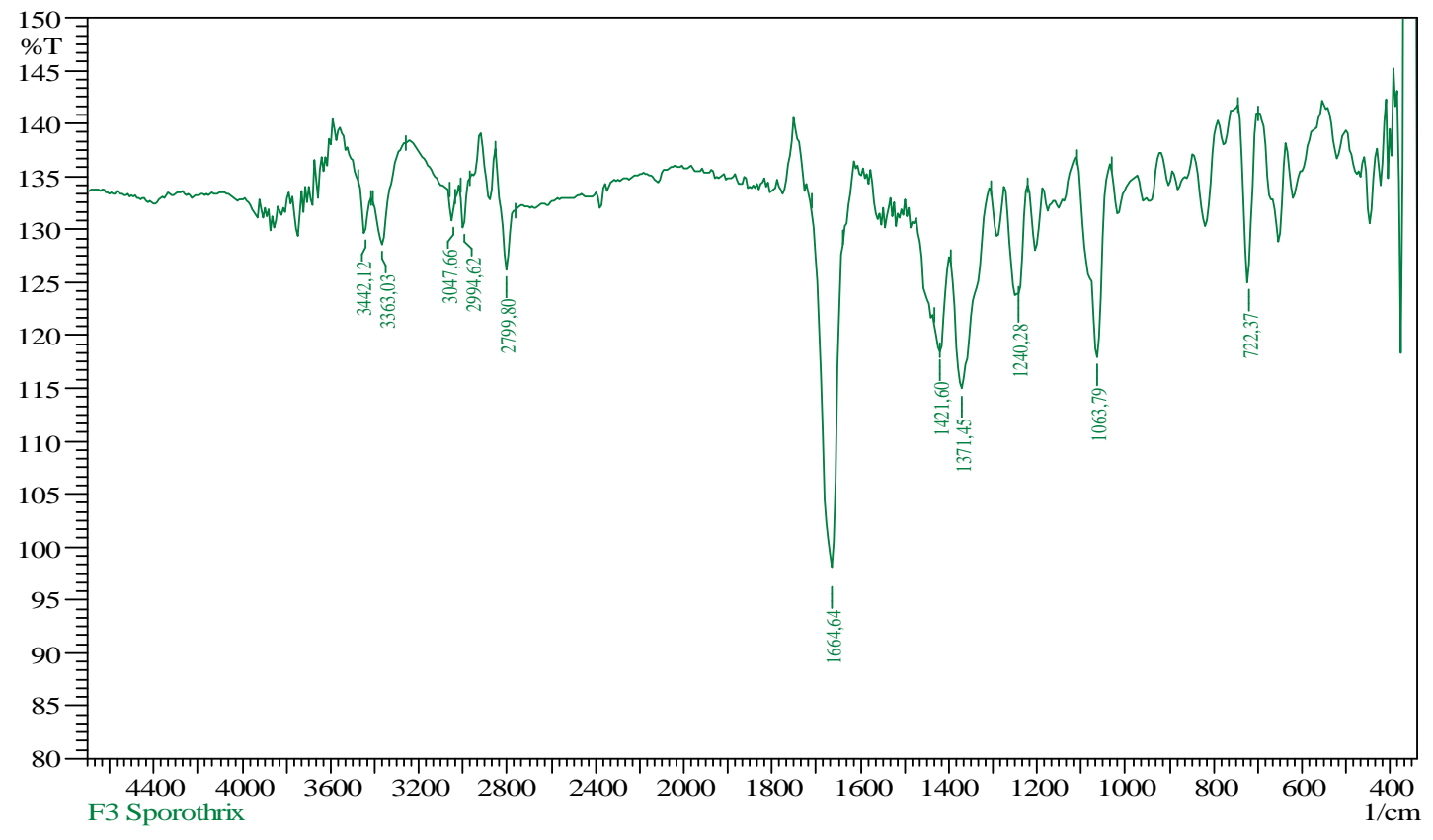


Spektrum infra merah menunjukkan adanya pita- pita untuk serapan untuk gugus amina N-H pada panjang gelombang 3300-3000 $\mathrm{cm}^{-1}$, Getara lentur N-H terbentang pada area 1650-1580 $\mathrm{cm}^{-1}$, untuk amina juga dapat terlihat pada area 910-665 $\mathrm{cm}^{-1}$. Getaran peregangan $\mathrm{C}-\mathrm{N}$ dari amina alifatik diamati sebagai pita sedang atau lemah di wilayah 1250$1020 \mathrm{~cm}^{1}$. Dalam amina aromatik, band ini biasanya kuat dan di wilayah 1335-1250 $\mathrm{cm}^{-1}$. $\mathrm{N}-\mathrm{H}$ peregangan $3400-3250 \mathrm{~cm}^{-1}, 1^{\circ}$ amina: dua pita dari 3400-3300 dan 3330-3250 $\mathrm{cm}^{-1}, 2^{\circ}$ amina: satu pita dari $3350-3310 \mathrm{~cm}^{-1}, 3^{\circ}$ amina: tidak ada band di wilayah ini $\mathrm{N}-\mathrm{H}$ bengkokan (hanya amina primer) dari $1650-1580 \mathrm{~cm}^{-1}$,
Peregangan $\mathrm{C}-\mathrm{N}$ (amina aromatik) dari 1335$1250 \mathrm{~cm}^{-1}, \mathrm{C}-\mathrm{N}$ stretch (aliphatic amines) dari 1250-1020 cm $\mathrm{cm}^{-1}$, N-H wag (primer dan sekunder hanya) dari $910-665 \mathrm{~cm}^{-1}$.

\section{Spektroskopi HPLC}

Pengukuran dengan menggunakan alat HPLC (High Performance Liquid Cromatography). Hasilnya dapat dilihat pada Gambar 2. Untuk uji kemurnian senyawa terlihat pada kromatogram bahwa satu puncak yang muncul, ini menandakan senyawa tersebut murni.

11/16/2017 1501747 1/1

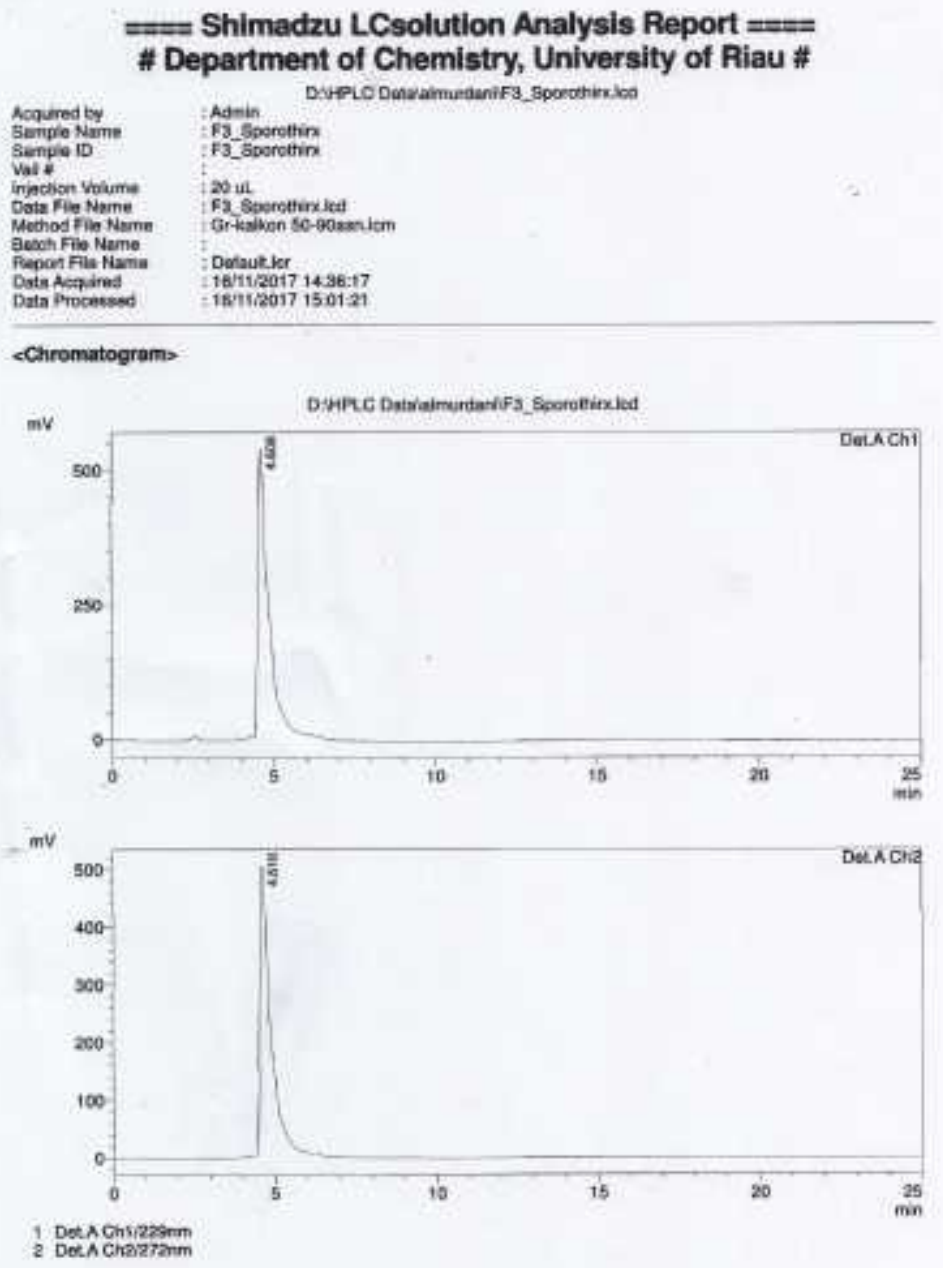


Pengujian senyawa hasil isolasi terhadap uji bakteri Escherichia coli dan Staphylococcus aureus. Uji bioaktivitas senyawa F3 Hasil isolasi terhadap bakteri tersebut dinyatakan pada Tabel 4.

Tabel 4. Uji Bioaktivitas senyawa F3 hasil isolasi terhadap E.coli dan Staphylococcus aureus dengan berbagai dosis.

\begin{tabular}{|c|c|c|c|c|}
\hline \multicolumn{5}{|c|}{ Rata-rata diameter hambat $(\mathrm{mm})$} \\
\hline Senyawa murni & & Dosis & ligunakan & \\
\hline F3 hasil isolasi. & $10 \mu \mathrm{g} / \mathrm{disk}$ & $30 \mu \mathrm{g} / \mathrm{disk}$ & $50 \mu \mathrm{g} / \mathrm{disk}$ & $\mathrm{K}+$ \\
\hline Escherichia coli & 29,10 & 32,60 & 38,40 & 47,60 \\
\hline Staphylococcus aureus & 29,40 & 29,80 & 31,40 & 45,10 \\
\hline
\end{tabular}

Zona hambat yang terbentuk terlihat pada Gambar 3 dibawah ini.

1. Terhadap Bakteri Escherichia coli

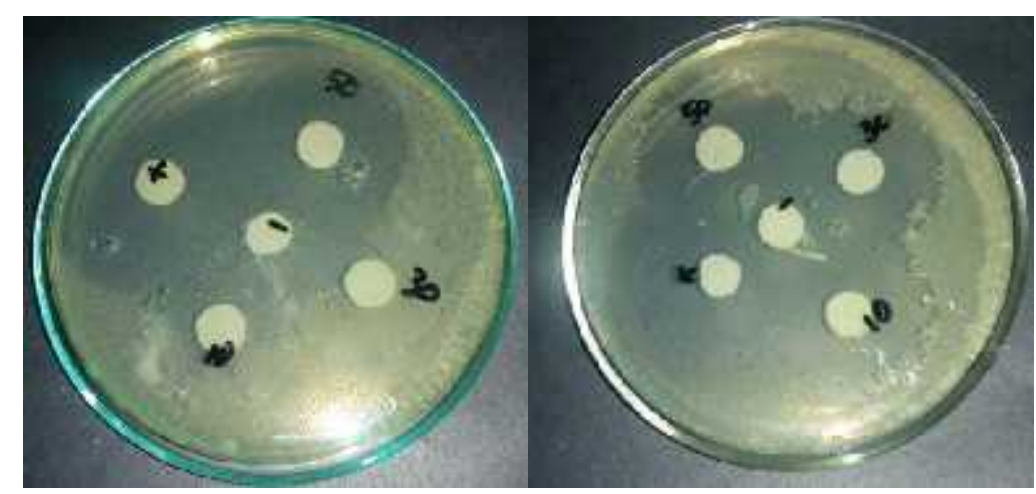

2. Terhadap Bakteri Staphylococcus aureus

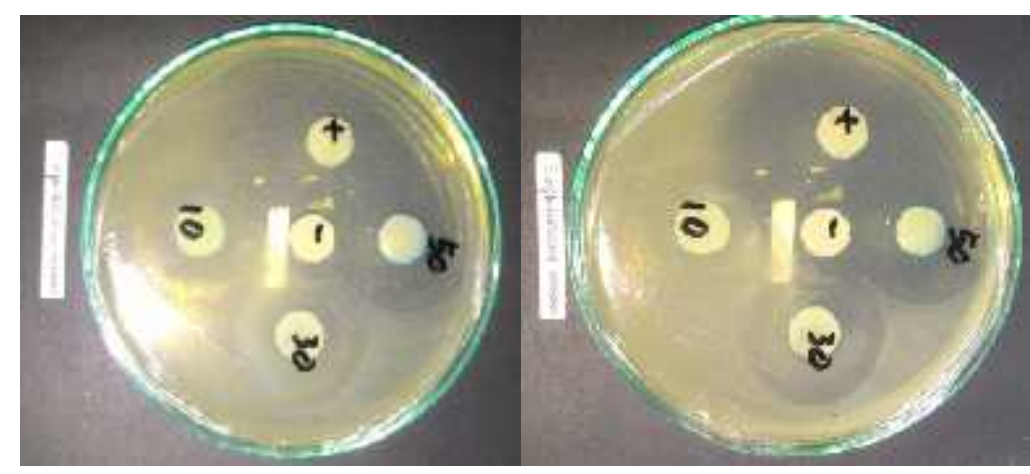

Gambar 3. Zona hambat yang terbentuk pada variasi media Huang et al(2007)dengan dosis 10, 30 dan $50 \mu \mathrm{g} / \mathrm{disk}$.

\section{PEMBAHASAN}

Hasil uji daya hambat senyawa murni F3 diatas terlihat senyawa murni tersebut memberikan daya hambat yang besar pada dosis $50 \mu \mathrm{g} /$ disk yang terlihat pada daya hambat terhadap bakteri Escherichia coli 38,40mm. Pada bakteri Staphylococcus aureus juga memberikan daya hambat sebesar 31,40mm, sedangkan pada kontrol positif ciproploxacin sebesar $47,60 \mathrm{~mm}$.

Pemilihan ciprrofloxacin sebagai kontrol positif karena ciprofloxacin merupakan golongan obat flouoquinolon yang berfungsi untuk menghambat sintesis DNA bakteri sehingga menghambat resistensi mikroba dan merupakan antimikroba berspektrum luas dan resistensi mikroba tidak cepat berkembang. (6). 
Pada bakteri Escherichia coli dosis 10 dan $50 \mu \mathrm{g} /$ disk memberikan daya hambat yang bermakna pada senyawa F3 hasil isolasi. Berbeda dengan Staphylococcus aureus tidak ada perbedaan dosis yang bermakna baik dosis 10,30 dan $50 \mu \mathrm{g} /$ disk. Dari bentuk kromatogram yang ditemukan dari hasil spektofotometer IR dan HPLC, adanya gugus amina yang secara umum dapat berfungsi sebagai antibakteri dan anti jamur.

Dari hasil analisa HPLC dan Spektrofotometer IR, senyawa murni F3 mengandung senyawa terpenoid yang fungsinya membunuh bakteri dengan mendenaturasi protein sel dimana terjadinya ikatan protein sel dengan senyawa terpenoid yang mengakibatkan protein sel tersebut rusak. Ikatan hidrogen yang terbentuk akan menganggu permebealitas dinding sel dan membran sitoplasma yang keduanya tersusun dari protein. Permeabilitas dinding sel dan membran sitoplasma terganggu akan menyebabkan ketidakseimbangan makromolekul dan io dalam sel sehingga terjadi lisis sel . terpenoid juga mampu berikatan denga lemak dan karbohidrat yang menyebabkan permeabilitas dinding sel bakteri terganggu (29).

\section{SIMPULAN}

Hasil uji anti bakteri senyawa murni terhadap Escherichia coli memberikan daya hambat bermakna pada dosis 10 dan $50 \mu \mathrm{g} /$ disk dan Stapylococcus aureus tidak ada yang berbeda nyata untuk ketiga dosis.

\section{UCAPAN TERIMA KASIH}

Ucapan terima kasih penulis ucapkan kepada pihak-pihak yang telah membantu dalam terlaksananya penelitian ini.

\section{DAFTAR PUSTAKA}

Strobel,G \& Daisy,B.2003. Bioprospecting for Microbial Endophytes and Their Natural Products. Microbiology and Molecular Biology Reviws 67: 491-502.

Saryono,et al, 2015, Antimicrobial activity and molecular characterization of endophytic fungi strain isolated from Dahlia (Dahlia variabilis), Journal of Chemical and Pharmaceutical Research, vol 7((S): 201-208, ISSN 0975-7384.
Elita, A., Saryono, S.,dan Christine, J., 2013, Penentuan Waktu Optimum Produksi Antimikroba dan Uji Fitokimia Senyawa uji fermentasi bakteri endofit pseudomonas Sp. dari umbi tanaman Dahlia (dahlia variabilis), Journal Ind. Che. Acta Vol 3 (2) 56 62.

Fitriyah, D., Saryono. S, dan C. Jose., 2013, Skrining aktivitas antimikroba dan uji fitokimia dari kapang endofitik tanaman dahlia (dahlia variabilis), Journal Ind. Che. Acta Vol 3 (2) 50-55

Gan, V.H.S dan Setiabudy, R. 2000. Farmakologi Dan Terapi. Edisi 3. Jakarta: Bagian Farmakologi Fakultas Kedokteran Universitas Indonesia.

Guo B, Dai J, Ng S, Huang Y, Leong C, Ong W, Carte BK.. 2002. Cytonic acid A dan $B$, novel tridepside inhibitor of hCMV protease from the endophytic fungus Cytonaena sp. J Nat Prod 63:602-604.

Halim, Jasril, dan Saryono, 2014, Optimalisasi Produksi Senyawa Metabolit Sekunder dari Pseudomonas sp Endofit Tanaman Dahlia (Dahlia variabilis), Ind.Che.Acta vol 5(1) 8-14.

Haniah.M, 2008, Isolasi jamur Endofit dari Daun Sirih (Piper betle L) Sebagai Antimikroba Terhadap Eschericia coli, Staphylococcus aureus dan Candida albicans,UIN Malang.

Haryani,Y., Siti Muthmainah dan Saryono Sikumbang, 2013, Uji Parameter Non Spesifik dan Aktivitas Antibakteri Ekstrak Metanol dari Umbi Tanaman Dahlia (Dahlia variabilis), Jurnal Penelitian Farmasi Indonesia 1(2), Maret 2013: 43-46.

Huang, W.Y., Cai, Y.Z., Hyde, K.D., Corke, H., \& Sun, M. 2007. Endophytic fungi from Nerium oleander L (Apocynaceae) main constituents and antioxidant activity. World Journal of Microbiology and Biotechnology 23(9)1253-1263.

Lorenita,M.,et al, 2013, Screening of Endophytic Fungi from Tubers of Dahlia variabilis, Journal of Agricultur Technology, vol 9(3): 565-570.

$\mathrm{Lu} \mathrm{H}$, Zou WX, Meng JC, Hu J, Tan RX. 2000. New bioactive metabolites 
produced by Colletotrium sp., an endophytic fungus in Artemisia annua. Plant Sci151:76-73.

Purwantini, I, Ratna H, A. Dan Eka P. P, 2010, Isolasi Fungi Endofit Penghasil Antifungi dari Eupatorium riparium Reg. Dan Identifikasi Senyawa Aktifnya Menggunakan Bioautografi, Prosiding Seminar nasional, Eight performance Pharmacist, 27 Desember 2010, UGM Yogyakarta, hal 149.

Prihatiningtias,W. 2007. Prospek Mikrob Endofit Sebagai Sumber Senyawa Bioaktif, Majalah Obat Tradisional 12 (42).

Pratiwi,S.T, 2008. Mikrobiologi Farmasi,Jakarta, Erlangga.

Qadri, M, et,al, 2013, Identification and bioactive potential of endophytic fungi isolated from selected plants of the Western Himalayas, Qadriet al. Springer Plus 2013,2:8, 2-14.

Radji, M. 2005. Peranan Bioteknologi dan Mikroba Endofit dalam Pengembangan Obat Herbal. Laboratorium Mikrobiologi dan Bioteknologi. Vol. II. Departemen Farmasi, FMIPA-UI, Majalah Ilmu Kefarmasian, ,No.3,Desember.

Rante, H, Burhanuddin Taebe dan Soendaria Intan, 2013, Isolasi Fungi Endofit Penghasil Senyawa Antimikroba Dari Daun Cabai Katokkon (Capsicum annuum L var. chinensis) dan profil KLT BIOAUTOGRAFI, Majalah Farmasi dan Farmakologi, Vol. 17, No. 2 - Juli 2013, hlm. 39 - 46.

Ryan.J.K, 2004, Medical Microbiology, An Introduction to Infectious Diseases, Prentice Hall International Inc.

Ristiati, N. P. 2000. Pengantar Mikrobiologi Umum. Proyek Pengembangan sekolah menengah IBRD Loan Direktorat Jendral Pendidikan Tinggi: Departemen Pendidikan Nasional.

Saryono S.dkk.2013, Penentuan Waktu Optmum Produksi Antimikroba dan Uji Fitokimia Ekstrak Kasar Fermentasi Bakteri Endofit Pseudomonas sp dari Umbi Tanaman Dahlia (Dahlia variabilis),Jurnal.Ind,Che.Acta Vol.3 (2) 2013.
Saryono, Hindersah,2009, Tanaman Dahlia Potensi Bahan Alam Sumber Karbohidrat dan Senyawa Bioaktif, Unri Press, Pekanbaru.

Sadrati, N, et al, 2013, Screening of Antimicrobial And Antioxidant Secondary Metabolites From Endophytic Fungi Isolated From Wheat (Triticum Durum), Journal Of Plant Protection Research Vol. 53, No. 2: 128-136.

Selim, KA, El-Beih AA, Abd El-Rahman TM and El-Diwany AI, 2012, Biology of Endophytic Fungi, Current Research in Environmental \& Applied Mycology, 31-81.

Simarmata, Rumilla. 2007. Isolasi Mikroba Endofitik dari Tanaman Obat Sambung Nyawa Gynura Procumbens) dan Analisis Potensinya sebagai Antimikroba. Jurnal penelitian Hayati $13: 85-90$.

Sinaga,E. dkk,2009, Daya antibakteri Jamur Endofit yang Diisolasi Dari Dan Dan Rimpang Lengkuas (Alpinia galanga $s w)$, Jurnal Farmasi Indonesia vol 4.no4 Juli 2009 :161-170.

Sinaga,E,dkk, 2009, Isolasi dan Uji Aktivitas Antibakteri Jamur Endofit DariDaun Dan Rimpang Zingiber ottensii Val, Jurnal Farmasi Indonesia,vol 4.(4) : 171-176.

Simanjuntak P, Parwati T, Bustanussalam, Prana TK, Wibowo S, Shibuya $\mathrm{H}$. 2002. Isolasi dan kultivasi mikroba endofit penghasil senyawa alkaloid kinkona dari Chinchona spp. J Mikrobiol 7:27-30.

Shinta, D.Y, et al, 2015, The Media Variance of Production for Anti Microbe Homogeny from the Endofite Mushroom of Dahlia Plant Seed (Dahlia variabilis), Journal of Chemical and Pharmaceutical Research, 7(9S): 239245.

Bonjura,S.,dkk, 2015, Uji anti bakteri ekstrak daun Leilem (Clerodendum minahassae.L) Terhadap Bakteri Streptococcus mutan, Jurnal Ilmiah Farmasi Unsrat Vol4 no 4, ISSN 23022493. 